\title{
Pengaruh Profitabilitas, Likuiditas, dan Leverage terhadap Pengungkapan Corporate Social Responsibility (CSR) pada Perusahaan Pertambangan yang Terdaftar di Bursa Efek Indonesia Tahun 2014 - 2017
}

\author{
KRISTINAAPRILIANI PUTRI \\ ELMAMUNCAR ADITYA \\ NURDHIANA
}

\author{
Sekolah Tinggi Ilmu Ekonomi Widya Manggala \\ Jalan Sriwijaya No. 32 \& 36 Semarang 50242 \\ Email :kristina.apriliani@yahoo.com
}

\section{Diterima 3 September 2019; disetujui 17 September 2019}

\begin{abstract}
This study aimed to find out the effect of variables such as profitability, liquidity, and leverage on Corporate Social Responsibility (CSR) Disclosure. Type of this research used was quantitative research. The total companies used in this research were 27 mining companies listed in Indonesia Stock Exchange (IDX) period 2014-2017. This research used multiple linier regression analysis. Partially Profitability (ROE) had a significant positive effect on CSR Disclosure, while Liquidity (Current Ratio) and Leverage (DER) had no effect on CSR Disclosure. The result also showed that simultaneously Profitability (ROE), Liquidity (Current Ratio) and Leverage (DER) had a significant positive effect on CSR Disclosure.
\end{abstract}

Keywords: Corporate Social Responsibility, Profitability, Liquidity, Leverage

\section{PENDAHULUAN}

Latar Belakang. Social responsibility dengan perjalanan waktu menjadi bagian yang tak terpisahkan dari keberadaan perusahaan. Hal itu karena keberadaan perusahaan di tengah lingkungan memiliki dampak positif maupun negatif. Dampak negatif (negative externalities) memicu reaksi dan protes stakeholder, sehingga perlu penyeimbangan lewat peran social responsibility sebagai salah satu strategi legitimasi perusahaan. Menurut Hadi (2009) social responsibility memiliki kemanfaatan (konsekuensi) baik secara sosial (social consequences) maupun konsekuensi ekonomi (economic consequences). Kendatipun social responsibility memiliki kemanfaatan secara sosial dan ekonomi, namun ternyata perusahaan memandang secara berbeda. Perbedaan persepsi tersebut berada secara diametral, yaitu terdapat perusahaan yang memandang bahwa tanggungjawab sosial perusahaan bukan merupakan kewajiban mereka, bahkan social responsibility mengandung biaya yang relatif besar yang justru menggangu profitabilitas perusahaan, dan secara tidak langsung juga mempengaruhi likuiditas serta leverage perusahaan.

Penelitian ini mengacu pada penelitian yang dilakukan oleh Putri dan Christiawan (2014), dimana terdapat tiga variabel independen yang diuji yaitu profitabilitas, likuiditas dan leverage yang berpengaruh terhadap pengungkapan corporate social responsibility sebagai variabel dependennya pada perusahaan-perusahaan yang mendapat penghargaan ISRA dan Listed (Go-Public) di Bursa Efek Indonesia (BEI) 2010-2012. Perbedaan 
penelitian ini dengan penelitian sebelumnya adalah pada pengambilan sample, penelitian ini mengambil sample seluruh populasi berjumlah 27 perusahaan pertambangan yang terdaftar di BEI yang mempublikasikan laporan tahunan atau Annual Report secara berturut-turut selama empat tahun yaitu tahun 2014-2017. Penggunaan industri pertambangan sebagai sampel penelitian karena industri pertambangan termasuk dalam industri high profile yang memiliki visibilitas dari stakeholder. Risiko politis yang tinggi dan menghadapi persaingan yang tinggi dan memperoleh sorotan dari masyarakat karena aktivitas operasinya memiliki potensi bersinggungan dengan kepentingan luas (stakeholder).

Tujuan Penelitian. Tujuan dalam penelitian ini adalah untuk menganalisis pengaruh profitabilitas, likuiditas dan leverage terhadap pengungkapan Corporate Social Responsibility (CSR) pada perusahaan pertambangan yang terdaftar di Bursa Efek Indonesia Tahun 2014-2017.

\section{TINJAUAN PUSTAKA}

Corporate Social Responsibility. CSR adalah suatu proses pengukuran, pencatatan, pelaporan dan pengungkapan informasi terkait dampak sosial dan lingkungan dari tindakantindakan ekonomi perusahaan terhadap kelompok - kelompok tertentu dalam masyarakat atau yang menjadi stakeholder perusahaan (Lako, 2011).

Menurut Widjaja (2008) Corporate Social Responsibility merupakan bentuk kerjasama antara perusahaan (tidak hanya perseroan terbatas) dengan segala sesuatu atau segala hal (stakeholders) yang secara langsung maupun tidak langsung berinteraksi dengan perusahaan tersebut untuk tetap menjamin keberadaan dan kelangsungan usaha (sustainability) suatu perusahaan.

CSR menurut Nor Hadi (2011), mengatakan CSR adalah komitmen berkelanjutan dari perusahaan yang berjalan secara etis dan memiliki kontribusi terhadap pembangunan untuk meningkatkan kualitas hidup tenaga kerja dan keluarga mereka, dan juga komunitas lokal serta masyarakat luas.

Profitabilitas. Rasio profitabilitas merupakan rasio untuk menilai kemampuan perusahaan dalam mencari keuntungan atau laba dalam suatu periode tertentu (Kasmir, 2017). Rasio ini juga memberikan ukuran tingkat efektivitas manajemen suatu perusahaan. Dalam mengukur profitabilitas perusahaan digunakan alat ukur return on equity (ROE). $\mathrm{ROE}$ merupakan suatu indikator keuangan yang menggambarkan kemampuan perusahaan dalam menghasilkan laba atas modal sendiri yang dimiliki perusahaan. Semakin tinggi rasio ini semakin baik. Artinya posisi pemilik perusahaan semakin kuat, demikian pula sebaliknya.

Menurut Sartono (2001) Profitabilitas adalah kemampuan perusahaan memperoleh laba dalam hubungannya dengan penjualan, total aktiva, maupun modal sendiri. Dengan demikian bagi investor jangka panjang akan sangat berkepentingan dengan analisa profitabilitas ini.

Riyanto (2001) menyatakan profitabilitas adalah kemampuan suatu perusahaan untuk menghasilkan laba selama periode tertentu.

Likuiditas. Rasio likuiditas merupakan rasio yang menggambarkan kemampuan perusahaan dalam memenuhi kewajiban jangka pendek (Kasmir, 2017). Fungsi lain rasio likuiditas adalah untuk menunjukan atau mengukur kemampuan perusahaan dalam memenuhi kewajibannya yang jatuh tempo, baik kewajiban kepada pihak luar perusahaan (likuiditas badan usaha) maupun di dalam perusahaan (likuiditas perusahaan). Atau dengan kata lain, ratio likuiditas menunjukkan kemampuan perusahaan untuk membayar hutang - hutang (kewajiban) jangka pendeknya yang jatuh tempo, atau rasio untuk mengetahui kemampuan perusahaan dalam membiayai dan memenuhi kewajibannya saat ditagih.

Likuiditas dapat diukur dengan ratio lancar (current ratio). Semakin tinggi angka ratio likuiditas, akan semakin baik bagi investor. Perusahaan yang diminati investor adalah perusahaan yang mempunyai rasio likuiditas yang cukup tinggi untuk standar perusahaan sejenisnya. Menurut Kamil dan Herusetya (2012), likuiditas merupakan suatu indikator kemampuan entitas untuk membayar semua liabilitas finansial jangka pendek pada saat jatuh tempo dengan menggunakan aset lancar yang tersedia.

Sependapat dengan Kamil dan Herusetyo (2012), Sutrisno (2003) juga berpendapat bahwa likuiditas merupakan kemampuan perusahaan untuk membayar kewajiban jangka pendeknya pada saat 
jatuh tempo.

Leverage. Ratio leverage merupakan rasio yang digunakan untuk mengukur sejauh mana aktiva perusahaan dibiayai dengan utang (Kasmir, 2017). Artinya berapa besar beban utang yang ditanggung perusahaan dibandingkan dengan aktivanya. Dalam arti luas dikatakan bahwa rasio leverage digunakan untuk mengukur kemampuan perusahaan untuk membayar seluruh kewajibannya, baik jangka pendek maupun jangka panjang apabila perusahaan dibubarkan (dilikuidasi).

Dalam praktiknya, apabila dari hasil perhitungan, perusahaan ternyata memiliki rasio leverage yang tinggi, hal ini akan berdampak timbulnya risiko kerugian lebih besar, tetapi juga ada kesempatan mendapat laba besar juga. Sebaliknya apabila perusahaan memiliki rasio leverage lebih rendah tentu mempunyai risiko kerugian lebih kecil pula, terutama pada saat perekonomian menurun. Dampak ini juga mengakibatkan rendahnya tingkat hasil pengembalian (return) pada saat perekonomian tinggi. Oleh karena itu perlu pengelolaan rasio leverage dengan baik sehingga mampu menyeimbangkan pengembalian yang tinggi dengan risiko yang dihadapi.

Rasio leverage dapat diukur dengan mengukur debt to equity ratio, yaitu menghitung perbandingan antara total utang dengan total ekuitas.

Menurut Irawati (2006), leverage merupakan suatu kebijakan yang dilakukan oleh suatu perusahaan dalam hal menginvestasikan dana yang disertai dengan adanya beban/biaya tetap yang harus ditanggung perusahaan.

Pengertian leverage menurut Sartono (2010) leverage adalah: "Leverage adalah penggunaan assets dan sumber dana (sources of funds) oleh perusahaan yang memiliki biaya tetap (beban tetap) dengan maksud agar meningkatkan keuntungan potensial pemegang saham".

Hipotesis. Berdasarkan tinjauan teoritis dan penelitian terdahulu, maka hipotesis yang diajukan dalam penelitian ini antara lain:

H1 : Profitabilitas berpengaruh signifikan positif terhadap pengungkapan CSR.

$\mathrm{H} 2$ : Likuiditas berpengaruh signifikan positif terhadap pengungkapan CSR.

H3 : Leverage berpengaruh signifikan negatif terhadap pengungkapan CSR

\section{METODE PENELITIAN}

Jenis Penelitian. Jenis penelitian yang digunakan adalah penelitian Kausal Komparatif. Menurut Indriantoro dan Supomo (2000) bahwa penelitian Kausal Komparatif merupakan tipe penelitian dengan karakteristik masalah berupa hubungan sebab-akibat antara dua variabel atau lebih. Dalam hal ini merupakan analisis faktor-faktor yang mempengaruhi pengungkapan Corporate Social Responsibility.

Variabel dan Indikator. Penelitian ini menguji apakah Pengungkapan Corporate Social Responsibility (CSRD) sebagai variabel dependen, dipengaruhi oleh variabel dependen yang terdiri dari Profitabilitas, Likuiditas, dan Leverage

CSRD diukur dengan angka indeks Corporate Social Responsibility Disclosure Index (CSRDI) hasil content analysis, berdasarkan indikator GRI (Global Reporting Initiatives)-G4 yang terdiri dari 91 item. Indikator GRI dipilih karena merupakan aturan internasional yang telah diakui oleh perusahaan di dunia. Pendekatan untuk menghitung CSRDI pada dasarnya menggunakan pendekatan dikotomi yaitu item CSR diberi score 1 jika diungkapkan dan score 0 jika tidak diungkapkan (Pradipta, 2015). Selanjutnya skor dari setiap item dijumlahkan untuk memperoleh keseluruhan score untuk setiap perusahaan.

Profitabilitas merupakan kemampuan perusahaan dalam mencari keuntungan atau laba dalam suatu periode tertentu (Kasmir, 2017). Variabel profitabilitas dalam penelitian ini diproksikan dengan Return on Equity (ROE). ROE merupakan suatu indikator keuangan yang menggambarkan kemampuan perusahaan dalam menghasilkan laba atas modal sendiri yang dimiliki perusahaan. Semakin tinggi rasio ini semakin baik. Artinya posisi pemilik perusahaan semakin kuat, demikian pula sebaliknya.

Likuiditas merupakan kemampuan perusahaan dalam memenuhi kewajiban jangka pendek. Perusahaan yang diminati investor adalah perusahaan yang mempunyai rasio likuiditas yang cukup tinggi untuk standar perusahaan sejenisnya. Dalam penelitian ini variable likuiditas diproksikan dengan Current Ratio. 
Leverage merupakan kemampuan perusahaan untuk membayar seluruh kewajibannya, baik jangka pendek maupun jangka panjang apabila perusahaan dibubarkan (dilikuidasi). Artinya berapa besar beban utang yang ditanggung perusahaan dibandingkan dengan aktivanya. Dalam arti luas dikatakan bahwa rasio leverage digunakan untuk mengukur kemampuan perusahaan untuk membayar seluruh kewajibannya, baik jangka pendek maupun jangka panjang apabila perusahaan dibubarkan (dilikuidasi). Variabel leverage diproksikan dengan debt to equity ratio (DER) yang menghitung perbandingan antara total utang dengan total ekuitas.

Populasi dan Sampel. Populasi dan sampel pada penelitian ini adalah seluruh perusahaan pertambangan yang terdaftar di BEI yang mempublikasikan laporan tahunan atau Annual Report secara berturut - turut selama empat tahun (2014 - 2017) sebanyak 27 perusahaan

Sumber Data. Dalam penelitian ini sumber data yang digunakan adalah data sekunder. Sumber data dalam penelitian menggunakan data sekunder yang berupa data internal perusahaan pertambangan yang terdaftar di BEI yang berupa: Laporan Tahunan atau Annual Report dan Indonesia Capital Market Directory (ICMD) Perusahaan Pertambangan dari tahun 2014 - 2017.

Teknik Analisis Data. Data yang telah terkumpul akan dianalisis dengan analisis regresi linier berganda. Analisis ini dipilih karena penelitian ini bertujuan untuk menguji arah dan pengaruh variabel independen yang terdiri dari profitabilitas, likuiditas, dan leverage; terhadap pengungkapan CSR (CSRD).

\section{HASIL DAN PEMBAHASAN}

Analisis Regresi Linier Berganda. Berdasarkan tabel 1 maka diperoleh persamaan regresi sebagai berikut :

$\mathrm{Y}=\mathrm{b}_{\mathrm{o}}+\mathrm{b}_{1} \mathrm{X}_{1}+\mathrm{b}_{2} \mathrm{X}_{2}+\mathrm{b}_{3} \mathrm{X}_{3}$ $Y=40,776+0,279 X_{1}-0,009 X_{2}-0,100 X_{3}$ Keterangan :

$\mathrm{Y}=$ = Pengungkapan corporate social responsibility.

$\mathrm{b}_{\mathrm{o}} \quad=$ konstanta

$\mathrm{b}_{1}, \mathrm{~b}_{2}, \mathrm{~b}_{3}=$ koefisien variabel bebas

$\mathrm{X}_{1} \quad=$ Profitabilitas
$\mathrm{X}_{2} \quad=$ Likuiditas

$\mathrm{X}_{3} \quad=$ Leverage

Persamaan regresi linier berganda diatas menun-jukkan bahwa :

1. Nilai konstanta sebesar 40,776 menyatakan bahwa jika variabel independen yaitu profitabilitas, likuiditas dan leverage dianggap konstan maka nilai pengungkapan Corporate Social Responsibility akan naik sebesar 40,776.

2. $b_{1}$ (nilai koefisien regresi $X_{1}$ ) sebesar 0,279 menyatakan bahwa setiap kenaikan profitabilitas (ROE) sebesar 1 satuan sedangkan variabel lain tetap (konstan), maka pengungkapan Corporate Social Responsibility akan mengalami kenaikan sebesar 0,279 satuan.

3. $b_{2}$ (nilai koefisien regresi $X_{2}$ ) sebesar $-0,009$ menyatakan bahwa setiap penurunan likuiditas (Current ratio) sebesar 1 satuan sedangkan variabel lain tetap (konstan), maka pengungkapan Corporate Social Responsibility tidak akan mengalami penurunan sebesar 0,009 satuan.

4. $b_{3}$ (nilai koefisien regresi $X_{3}$ ) sebesar -0,100 menyatakan bahwa setiap penurunan leverage (DER) sebesar 1 satuan sedangkan variabel lain tetap (konstan), maka pengungkapan Corporate Social Responsibility akan mengalami penurunan sebesar 0,100 satuan.

Koefisien Determinasi. Besarnya nilai Adjusted $\mathrm{R}^{2}$ sebesar 0.261 yang artinya independen profitabilitas (ROE), likuiditas (current ratio) dan leverage (DER) dapat menerangkan variabilitas sebesar 26,1\% dari variabel dependen Corporate Social Responsibility, sedangkan sisanya $73.9 \%$ dijelaskan dan oleh sebab-sebab lain variabel yang tidak diteliti dalam penelitian ini.

Pengujian Hipotesis. Uji hipotesis profitabilitas $\left(\mathrm{X}_{1}\right)$ terhadap pengungkapan Corporate Social Responsibility, karena nilai t hitung 2,195 $>\mathrm{t}$ tabel 1,983 dengan nilai signifikan $\mathrm{t}$ sebesar 0,000 yang lebih kecil dibandingkan dengan tingkat signifikan $\alpha=0,05$, maka kesimpulan Ho ditolak dan Ha diterima. Artinya bahwa variabel profitabilitas (ROE) berpengaruh signifikan positif terhadap pengungkapan Corporate Social Responsibility pada perusahaan pertambangan di Bursa Efek Indonesia (BEI) periode 2014-2017. 
Uji hipotesis Likuiditas $\left(\mathrm{X}_{2}\right)$ terhadap pengungkapan Corporate Social Responsibility, karena nilai thitung $-1,801<\mathrm{t}$ tabel 1,983 dengan nilai signifikan t sebesar 0,075 yang lebih besar dibandingkan dengan tingkat signifikan $\alpha=0,05$, maka kesimpulan Ha ditolak dan Ho diterima. Artinya bahwa variabel Likuiditas (Current ratio) tidak berpengaruh terhadap pengungkapan Corporate Social Responsibility pada perusahaan pertambangan di Bursa Efek Indonesia (BEI) periode $2014-2017$.

Uji hipotesis Leverage $\left(\mathrm{X}_{3}\right)$ terhadap pengungkapan Corporate Social Responsibility, karena nilai t hitung $-0,532<\mathrm{t}$ tabel 1,983 dengan nilai signifikan $\mathrm{t}$ sebesar 0,596 yang lebih besar dibandingkan dengan tingkat signifikan $\alpha=0,05$, maka kesimpulan Ha ditolak dan Ho diterima. Artinya bahwa variabel Leverage (DER) tidak berpengaruh terhadap pengungkapan Corporate Social Responsibility pada perusahaan pertambangan di Bursa Efek Indonesia (BEI) periode 2014-2017.

Pengaruh Profitabilitas Terhadap Pengungkapan Corporate Social Responsibility. Variabel profitabilitas (ROE) berpengaruh signifikan positif terhadap pengungkapan Corporate Social Responsibility. Berdasarkan teori stakeholders, pengungkapan CSR dilakukan untuk menyeimbangkan konflik antar stakeholders. Dengan adanya pengungkapan CSR, stake holders dapat mengevaluasi dan mengetahui sejauh mana perusahaan dalam melaksanakan peranannya sesuai dengan keinginan stakeholders, sehingga menuntut adanya akuntabilitas perusahaan atas kegiatan CSR yang telah dilakukannya. Dalam hal ini, perusahaan dapat menyesuaikan mengenai banyak sedikitnya pengungkapan CSR berdasarkan kebutuhannya akan konflik tiap stakeholders.
Selain itu, hubungan antara profitabilitas dan pengungkapan CSR juga didasari oleh teori legitimasi dimana pengungkapan tanggung jawab sosial perusahaan dilakukan untuk mendapatkan nilai positif dan legitimasi dari masyarakat. Adanya mekanisme corporate governance dan profitabilitas memberikan keyakinan perusahaan untuk melakukan pengungkapan tanggung jawab sosial perusahaan. Artinya, dengan mekanisme corporate governance dan profitabilitas yang mencukupi, perusahaan tetap akan mendapatkan keuntungan positif, yaitu mendapatkan legitimasi dari masyarakat yang pada akhirnya akan berdampak meningkatnya keuntungan perusahaan di masa yang akan datang. Penelitian ini sesuai dengan hasil penelitian Azwir, Elfi dan Vadela (2014), Rita, Roland, dan Faradilla (2010), Emi (2016) serta penelitian Gusti dan Ida (2014).

Pengaruh Likuiditas Terhadap Pengungkapan Corporate Social Responsibility. Variabel Likuiditas (Current ratio) tidak berpengaruh terhadap pengungkapan Corporate Social Responsibility. Gagalnya likuiditas untuk mempengaruhi pengungkapan CSR kemungkinan disebabkan karakteristik perusahaan pertambangan yang memiliki likuiditas lebih kecil dibandingkan jenis industry lainnya. Hal ini disebabkan karena bisnis pertambangan merupakan bisnis jangka panjang, yang baru dapat menerima uang tunai (cash inflow) setelah beberapa tahun bisnis berjalan.

Pengaruh Leverage Terhadap Pengungkapan Corporate Social Responsibility Variabel Leverage (DER) tidak berpengaruh terhadap pengungkapan Corporate Social Responsibility. Hal ini kemungkinan besar disebabkan karena krakteristik perusahaan pertambangan yang menggunakan proporsi hutang cukup tinggi dibandingkan perusahaan lainnya.

Tabel 1

Pengujian Analisis Regresi Linier Berganda

\begin{tabular}{lrccccc}
\hline \multirow{2}{*}{ Model } & \multicolumn{2}{c}{ Unstandardized Coefficients } & Standardized Coefficients & $\mathrm{t}$ & Sig. \\
\cline { 2 - 4 } & $\mathrm{B}$ & Std. Error & Beta & & \\
\hline 1 (Constant) & 40.776 & 1.815 & & 22.472 & .000 \\
ROE & .279 & .045 & .515 & 6.195 & .000 \\
Current_Ratio & -.009 & .005 & -.150 & -1.801 & .075 \\
DER & -.100 & .188 & -.044 & -.532 & .596 \\
\hline
\end{tabular}

a. Dependent Variable: CSR

Sumber : Data diolah (2019) 


\section{SIMPULAN}

Kesimpulan. Berdasarkan hasil penelitian yang telah dibahas pada bagian sebelumnya, dapat diambil kesimpulan sebagai berikut :

a. Profitabilitas $\left(\mathrm{X}_{1}\right)$ berpengaruh positif terhadap pengungkapan CSR (Y).

b. Likuiditas $\left(\mathrm{X}_{2}\right)$ tidak berpengaruh terhadap pengungkapan CSR (Y).

c. Leverage $\left(\mathrm{X}_{3}\right)$ tidak berpengaruh terhadap pengungkapan CSR (Y).

Saran. Berdasarkan hasil dan kesimpulan penelitian ini, maka ditemukan beberapa keterbatasan, yang dapat dijadikan saran untuk penelitian berikutnya, antara lain:

a. Bagi Investor. Hasil menunjukkan bahwa profitabilitas yang diproksikan dengan ROE merupakan prediktor terbaik dalam memprediksi pengungkapan CSR. sehingga penting bagi investor dengan kepedulian sosial tinggi, untuk menggunakan profitabilitas sebagai prediktor.

b. Bagi penelitian selanjutnya. Faktor keuangan bukan satu-satunya penentu pengungkapan CSR. penelitian selanjutnya dapat mempertimbangkan untuk memasukkan variabel tata kelola perusahaan (GCG) dan kepemilikan perusahaan ke dalam model penelitian.

\section{DAFTAR PUSTAKA}

Adeneye, Babatunde, Ahmed, Maryam. 2015. Corporate Social Responsibility and Company Performance. Journal of Business Studies Quaterly Vol.7 No.1.

Adisusilo, P. (2011). Pengaruh Pengungkapan Informasi Corporate Social Responsibility (CSR) dalam Laporan Tahunan terhadap Earnings Response Coefficient (ERC). Skripsi.

Ahmad, Kamil dan Antonius Herusetya. 2012. Pengaruh Karateristik Perusahaan terhadap Luas Pengungkapan Kegiatan Coorporate Sosial Responbility. Media Riset Akuntansi, Vol. 2, No.1, Februari 2012, hal.117.

Anggraini Eka, dkk. 2014. Analisis Investasi Portofolio Pasar Modal Syariah dengan Model Indeks Tunggal. Jurnal Administrasi
Bisnis. Vol. 17. No. 1. Universitas Brawijaya Malang.

Anugrah, Rita. Rolland Hutabarat, dan W. Faradilla. (2010). Pengaruh Ukuran Perusahaan, Leverage, dan Profitabilitas terhadap Pengungkapan Tanggung Jawab Sosial Perusahaan pada Perusahaan Manufaktur yang Listing di BEI. Jurnal Ekonomi. Vol 18. 1 Maret 2010.

Arikunto, Suharsimi. 2002. Prosedur Penelitian: Suatu Pendekatan Praktek. Edisi Revisi V, Jakarta: Rineka Cipta.

Azwir, Nasir., dkk. 2014. Pengaruh Karakteristik Perusahaan dan Corporate Governance terhadap Pengungkapan Sustainability Report pada Perusahaan LQ45 yang Terdaftar. Jurnal Ekonomi. Volume 22, No 1 Maret 2014.

Bambang, Riyanto. 2001. Dasar-dasar Pembelanjaan Perusahaan. BPFE, Yogyakarta.

Dermawan, Decky dan Tita Deitiana. 2014. Faktorfaktor yang Mempengaruhi Pengungkapan Corporate Social Responsibility. Jurnal Bisnis dan Akuntansi, Vol. 16, No. 2 Desember 2014. Hal 158-165.

Ghozali, Imam. 2018. SPSS. Aplikasi Analisis Multivariate Dengan Program IBM SPSS 25 Edisi 9. Badan Penerbit Undip: Semarang.

Ghozali, Imam dan Anis Chariri. 2007. Teori Akuntansi. Semarang: Universitas Diponegoro.

Gray et.al. 1995. Corporate Social and Environmental Reporting: A Review of The Literature and a Longitudinal Study of UK Disclosure. Accounting, Auditing and Accountability Journal. Vol. 8 No. 2 pp.47-77.

Gujarati, D.N. (2003) . Basic Econometrics. Forth Edition. New York: Mc.Graw-Hill.

Hadi, Nor. 2009. Interaksi Biaya Sosial, Kinerja Sosial, Kinerja Keuangan, dan Luas Pengungkapan Sosial "Uji Praktik Social Responsibility Perusahaan Go Publik di Bursa Efek Indonesia" Disertasi Universitas Diponegoro. Tidak dipublikasikan.

Hadi, N. (2011). Corporate Social Responsibility. Yogyakarta: Graha Ilmu.

Hussainey, et. al. (2011). Factors Affecting Corporate Social Responsibility Disclosure In Egypt. School of Commerce and Law, Faculty of Arts, Business, informatics \& Education, Central Queensland University, Bruce Highway, North Rockhampton, 4702 Queensland,Australia.

Ikatan Akuntan Indonesia (IAI).2002. Standar Akuntansi Keuangan. Jakarta: Salemba 
Empat.

Indraswari, Gusti Ayu Dyah dan Ida Bagus Putra Astika. 2014. Pengaruh Profitabilitas, Ukuran Perusahaan, dan Kepemilikan Saham Publik pada Pengungkapan Corporate Social Resposibility pada Perusahaan Makanan dan Minuman berkategorikan High Profile yang terdaftar di BEI 20102012. E-Jurnal Akuntansi Universitas Udayana 9.3 (2014): 816-828.

Indriantoro, Nur, dan Bambang Supomo. 1999. Metodologi Penelitian dan Bisnis. Yogyakarta: BPFE Yogyakarta.

Jonathan, Sarwono. 2006. Metode Penelitian Kuantitatif dan Kualitatif. Yogyakarta :Graha Ilmu

Kamil, Ahmad dan Antonius Herusetya.2012. Pengaruh Karakteristik Perusahaan terhadap Luas Pengungkapan Kegiatan Corporate Social Responsibility.Media Riset Akuntansi, Vol.2, No.1. Februari 2012.

Kasmir, 2017. Analisis Laporan Keuangan, Penerbit PT. Raja Grafindo Persada, Jakarta.

Lako, Andreas. 2011. Dekonstruksi CSR dan Reformasi Paradigma Bisnis dan Akuntansi, Semarang:Erlangga.

Mandagie, Yuana, Rafrini Amyulianthy, Shanti Lysandra, Ari Pratiwi. 2018. Analisis Rasio Keuangan dan Laporan Corporate Social Responsibility Perusahaan Go Public di Indonesia. Jurnal Riset Akuntansi dan perpajakan JRAP Vol. 5. No. 2. Desember 2018. Hal 131-143.

Masyitah, Emi. 2016. Faktor-faktor yang Mempengaruhi Pengungkapan Sosial ( Social Disclosure) Dalam Laporan keuangan Tahunan Perusahaan Manufaktur yang Terdaftar di Bursa Efek Indonesia. Jurnal AlQasd, Vol 1 No, 1 Agustus 2016, Hal 52-70.

Mudjiyanti, Rina dan Salis Saevy Maulani. 2017. Pengaruh Likuiditas dan Profitabilitas Terhadap pengungkapan Corporate Social Responsibility pada perusahaan yang Terdaftar di Bursa Efek Indonesia. Jurnal Ekonomi dan Bisnis. Media Ekonomi. Vol. XVII. No. 1. Januari 2017.

Mustafa, Zaenal. 1995. Pengantar Statistik Terapan Untuk Ekonomi. Edisi kedua. Yogyakarta: BPFE UII.

Nur dan Priatinah. 2012. Analis Faktor-Fakto Yang Mempengaruhi Pengungkapan CSR Di Indonesia (Studi Empiris Pada Perusahaan
High Profile Yang Listing Di Bursa Efek Indonesia). Jurnal Nominal. Vol 1.

Novrianto.2012. Pengaruh Leverage, Profitabilitas, dan Ukuran Perusahaan Terhadap Pengungkapan Informasi Sosial Pada Perusahaan Manufaktur di BEI. Jurnal Ilmiah Mahasiswa Akuntansi Vol. 1 No. 1, Januari 2012.

Pradipta dan Supriyadi. 2015. Pengaruh Corporate Social Responsibility (CSR), Profitabilitas, Leverage, dan Komisaris Independen Terhadap Praktik Penghindaran Pajak. Jurnal. Universitas Gadjah Mada.

Putri, Rafika Anggraini dan Yulius Jogi Christiawan. 2014. Pengaruh Profitabilitas, Likuiditas, dan Leverage terhadap Pengungkapan Corporate Social Responsibility Perusahaanperusahaan yang Mendapat Penghargaan ISRA dan Listed di Bursa Efek Indonesia 2010-2012. Business Accounting Review, Vol 2, No. 1, 2014.

Ramdhaningsih Amalia dan I Made Karya Utama. 2013. Pengaruh Indikator Good Corporate Governance dan Profitabilitas Pada Pengungkapan Corporate Social Responsibility. EJurnal Akuntansi Univesitas Udayana. Bali.

Sari, Ratna Candra dan Zuhrotun. 2006. Keinformatifan Laba di Pasar Obligasi dan Saham : Uji Liquidation Option Hypothesis. Simposium Nasional Akuntansi 9: Padang

Sartono, Agus. 2001. Manajemen Keuangan Teori dan Aplikasi. Yogyakarta : BPFE-Yogyakarta.

Sekaran Uma. 2007. Metodologi Penelitian Bisnis. Erlangga, Jakarta.

Solihin, Ismail. 2008. Corporate Social Responsibility from Charity to Sustainability. Jakarta: Salemba Empat.

Sudana, I Made dan Putu Ayu Arlindania W. 2011. Corporate Governance dan Pengungkapan Corporate Social Responsibility pada Perusahaan GoPublic di Bursa Efek Indonesia. Dalam Jurnal Manajemen Teori dan Terapan, 4(1): h:37-49.

Susan, Irawati. 2006. Manajemen Keuangan. Bandung: Pustaka.

Sutomo, Ibnu. 2004. Pengaruh Rasio Likuiditas, Solvabilitas, Karakteristik Perusahaan Terhadap Luas Pengungkapan Sukarela pada Laporan Tahunan Perusahaan. Tesis. Semarang: Universitas Diponegoro.

Undang-Undang Republik Indonesia Nomor 40 
Tahun 2007 tentang Perseroan Terbatas.

Undang-Undang Republik Indonesia Nomor. 74

Tahun 2007 tentang Perseroan Terbatas.

Widjaja, Gunawan, 2008, 150 Tanya Jawab Tentang

Perseroan Terbatas, Jakarta: Forum Sahabat

Wijaya, Maria. 2012. Faktor-faktor yang Mem- pengaruhi Tanggung Jawab Sosial pada Perusahaan Manufaktur yang Terdaftar di Bursa Efek Indonesia. Jurnal Ilimiah Mahasiswa Akuntansi.Vol. 1, No. 1, Januari 2012.

www.idx.com. 